\title{
PROBLEM OF ANTIBIOTICS IN NATURAL WATER: A REVIEW
}

\author{
M. Litynska ${ }^{1}$, S. Kyriil ${ }^{1}$, O. Nosovska ${ }^{1}$, N. Ryzhenko ${ }^{1}$ \\ ${ }^{1}$ National Technical University of Ukraine “Igor Sikorsky Kyiv Polytechnic Institute”, Ukraine, \\ m.litynska-2017@kpi.ua
}

DOI: https://doi.org/10.20535/2218-930032021247159

The paper is devoted for influence of antibiotics contamination of natural water on environment, aquatic biosystems and public health and possible solutions of this problem. Untreated or ineffectively treated wastewater is a source of different pathogenic microorganisms and toxic chemicals, including organic and inorganic compounds. A lot of organic contaminants are genotoxic, provoke endocrine disruption and have immune toxicity. In modern world people use a lot of diverse antibiotics for the treatment of various bacterial infections, but antibiotic overuse and insufficient removal by wastewater treatment plants are resulted in accumulation and biotransformation of these compounds in aquatic environment. Antibiotics are pollutants which are very harmful for environment. They cause reduction in microbial biodiversity, including bacterial communities with important ecological functions. It provokes changes in water and soil properties, including $\mathrm{pH}$, nutrients content, soil moisture and many others. Low concentrations of antibiotics cause an occurrence of pathogenic microorganisms which are resistant to antibiotics. It has very negative influence on public health due to increasing of health risk and complication of a medication. Antibiotic type, water and sediment compositions, $\mathrm{pH}$, organic matter, specific surface area and temperature and insolation level have very big influence on distribution and behavior of antibiotics in natural water-sediment systems. Many antibiotics are biodegradable; they are transformed in human organism or by aquatic ecosystem (various plants, algae, bacteria, fungi, etc.). But some antibiotics, including ciprofloxacin, are very stable. These persistent organics are dramatically more harmful for ecosystem stability. In case of ciprofloxacin antibiotics in surface water direct photolysis causes formation of organic compounds, which are more toxic and less photolabile than initial antibiotics. So, the toxicity of pollutants increases synergistically and it cannot be ignored. Nowadays antibiotics removal is very important in drinking water and wastewater treatment due to significant environment and health effects of these pollutants. There are a lot of approaches in antibiotic removal from water, including adsorption, nanofiltration, advanced oxidation processes, etc. All these methods have some advantages and disadvantages. Catalytic photodegradation is one of the most popular methods of antibiotic removal. This process is simple, highly effective and makes possible transformation of antibiotics into components with lower toxicity and environmental impact. Also photocatalysis do not produce a lot of wastes unlike coagulation (sludge) or nanofiltration (concentrate).

Keywords: antibiotics contamination, antibiotic removal, wastewater, water pollution, water treatment

\section{Introduction}

\begin{tabular}{l}
\hline \multicolumn{2}{c}{ Insufficient drinking water and } \\
wastewater treatment are critical \\
environmental and public health problems.
\end{tabular}

Untreated or ineffectively treated wastewater is a source of different pathogenic microorganisms and chemicals, including organic and inorganic pollutants. Presence of phosphates and various persistent organic 
compounds is one of markers of wastewater contamination of aquatic environment (Patel et al., 2020). Phosphates enrichment in surface water causes eutrofication and some other negative effects for environment (Kumararaja et al., 2019). For example, during last years algae blooming in the biggest Ukrainian river becomes more and more catastrophic due to the high nutrients content in water and climate changes. From 2010 to 2017, the area of overgrown Dnipro River within Kyiv reaches $7.5 \%$ of the total water surface (Tomchenko et al., 2020).

An influence of different organic pollutants is less noticeable, but no less harmful to environment and public health. A lot of these compounds are genotoxic, provoke endocrine disruption and have immune toxicity (Patel et al., 2020). Antibiotics are among the most harmful for environment pollutants. They cause reduction in microbial biodiversity, including bacterial communities with important ecological functions (Grenni et al., 2018). It provokes changes in water and soil properties. Low concentrations of antibiotics (nanograms per liter or kilogram of soil) cause an occurrence of pathogenic microorganisms which are resistant to antibiotics. It has very negative influence on public health (Willyard, 2017).

So, nowadays antibiotics removal is very important in drinking water and wastewater treatment due to significant environment and health effects of these pollutants.

\section{Antibiotics in Aquatic}

\section{Environment}

In modern world people use a lot of diverse antibiotics for the treatment of various bacterial infections. But antibiotic overuse and insufficient removal by wastewater treatment plants are resulted in accumulation and biotransformation of these pollutants in aquatic environment (Roy et al., 2021).

Antibiotics presence in environment can cause detrimental effects due to the emergence of multi-resistant bacterial genes which increase the chances of pathogenic bacteria survival (Roy et al., 2021). As a result people need more and more novel antibiotics for the treatment of infections. According to (Jiang et al., 2013), various antibiotic resistance genes (two sulfonamide, eight tetracycline and one $\beta$-lactam) were detected in water samples of the Huangpu River (China) and the drinking water sources of Shanghai (China). In effluent water of sewage treatment plant (STP) in Beijing (China) 13 antibiotic resistance genes were detected (6 tetracycline, 3 sulfonamide and 4 quinolone) (Xu et al., 2015).

Antibiotic concentrations in natural water or soil are not high, from a few nanograms to hundreds of nanograms per liter or kilogram (Table 1). The most significant antibiotic contamination is in areas with strong anthropogenic pressures, especially hospital effluents, wastewater discharge, fields treated with manure or soils used for livestock (Grenni et al., 2018).

Antibiotic type, water and sediment compositions, $\mathrm{pH}$, organic matter, specific surface area and temperature and insolation level have very big influence on distribution and behavior of antibiotics in natural watersediment systems (Tang et al., 2019).

In hospital effluents there are different types of antibiotics, but in aquaculture, especially at fish and shrimp farms, such fluoroquinolones as enrofloxacin and ofloxacin are the most popular (Binh et al., 2018). 
Sunlight has very important role in antibiotic behavior in surface water. According to (Wang \& Lin, 2012), such cephalosporin antibiotics as cefazolin and cephapirin are mainly transformed by direct photolysis, while cephalexin and cephradine are mainly destructed by indirect photolysis. Direct photolysis causes formation of organic compounds, which are more toxic and less photolabile than initial antibiotics. In this case the toxicity of pollutants increases synergistically and it cannot be ignored.

Table 1. Antibiotic contamination

\begin{tabular}{|c|c|c|c|c|c|}
\hline Antibiotic & Concentration & $\begin{array}{l}\text { Type of } \\
\text { sample }\end{array}$ & Place & Country & Source \\
\hline tetracycline & $195 \mathrm{ng} / \mathrm{L}$ & $\begin{array}{l}\text { secondary } \\
\text { effluent }\end{array}$ & $\begin{array}{l}\text { STP in } \\
\text { Beijing }\end{array}$ & China & (Xu et al., 2015) \\
\hline sulfonamide & $2001 \mathrm{ng} / \mathrm{L}$ & $\begin{array}{l}\text { secondary } \\
\text { effluent }\end{array}$ & $\begin{array}{l}\text { STP in } \\
\text { Beijing }\end{array}$ & China & (Xu et al., 2015) \\
\hline quinolone & $3866 \mathrm{ng} / \mathrm{L}$ & $\begin{array}{l}\text { secondary } \\
\text { effluent }\end{array}$ & $\begin{array}{l}\text { STP in } \\
\text { Beijing }\end{array}$ & China & (Xu et al., 2015) \\
\hline $\begin{array}{c}\text { lincomycin } \\
\text { (lincosamide) }\end{array}$ & $1.2-248.9 \mathrm{ng} / \mathrm{L}$ & river water & Po River & Italy & (Grenni et al., 2018) \\
\hline $\begin{array}{l}\text { clarithromycin } \\
\text { (macrolide) }\end{array}$ & $8.3-149.0 \mathrm{ng} / \mathrm{L}$ & river water & $\begin{array}{l}\text { Lambro } \\
\text { River }\end{array}$ & Italy & (Grenni et al., 2018) \\
\hline $\begin{array}{l}\text { sulfadiazine } \\
\text { (sulfonamide) }\end{array}$ & $236 \mathrm{ng} / \mathrm{L}$ & river water & Tiber River & Italy & (Grenni et al., 2018) \\
\hline $\begin{array}{c}\text { ofloxacin } \\
\text { (fluoroquinolone) }\end{array}$ & $306.1 \mathrm{ng} / \mathrm{L}$ & river water & $\begin{array}{l}\text { Lambro } \\
\text { River }\end{array}$ & Italy & (Grenni et al., 2018) \\
\hline $\begin{array}{c}\text { cyprofloxacin } \\
\text { (quinolones) }\end{array}$ & $1.3-124 \mathrm{ng} / \mathrm{L}$ & river water & Po River & Italy & (Grenni et al., 2018) \\
\hline $\begin{array}{c}\text { enrofloxacin } \\
\text { (fluoroquinolone) }\end{array}$ & $680 \mathrm{ng} / \mathrm{L}$ & wastewater & $\begin{array}{l}\text { Pangasius } \\
\text { catfish farm }\end{array}$ & Vietnam & (Binh et al., 2018) \\
\hline $\begin{array}{c}\text { ofloxacin } \\
\text { (fluoroquinolone) }\end{array}$ & $238.6 \mathrm{ng} / \mathrm{L}$ & wastewater & shrimp farm & Vietnam & (Binh et al., 2018) \\
\hline
\end{tabular}

Colloidal organic matter is often component of surface water and plays a big role in the indirect photolysis of such fluoroquinolone antibacterials as ofloxacin and enrofloxacin due to adsorption processes and binding of Fe (Cheng et al., 2018).

Dissolved organic matter is other usual component of surface water. It stimulates the photodegradation of cefradine (cephalosporin antibiotic) by $9 \%$ (Jiang et al., 2010). Besides dissolved organic carbon, chloride-ions, bromide-ions, $\mathrm{pH}$ and light conditions, trivalent iron and nitrate-ions also have impact on the photodegradation of fluoroquinolone antibiotics (ciprofloxacin, enrofloxacin, sarafloxacin, danofloxacin, levofloxacin, difloxacin, balofloxacin and gatifloxacin) due to their photoreactivity in sunlit conditions of surface waters (Ge et al., 2010). Bicarbonate-enhanced nitrate system has significant positive influence on 
elimination process of cephalexin, cephradine and cefotaxime (Wang \& Lin, 2012). But without special treatment complete degradation of antibiotics, their metabolites and destruction by-products are very longterm process and the ecosystem harm is significant.

Thereby, careful treatment of antibioticcontaining wastewater is extremely important for mitigation of harmful action of anthropogenic activity on environment and public health.

\section{Possible Treatment Methods}

The existing household-wastewater treatment system cannot remove pharmaceuticals (including antibiotics) from the water (Mansouri et al., 2021).

Usually, water treatment methods are divided into mechanical, physicochemical, chemical, biological, and combined. The expediency of applying one or another method in each case is determined by the impurities nature, cleaning efficiency, technological parameters of the process, etc. Most antibiotics are water-soluble chemicals that use physicochemical, chemical, biological, and combined removal methods.

The effectiveness of methods for neutralizing antibiotics (biodegradation, coagulation, sedimentation) is often low, and the accumulation of these compounds in the environment leads to the destruction of microflora and fauna. Their background concentrations in water make the evolution of antibiotic-resistant bacteria in the environment (Balcioglu \& Ötker, 2003).

\subsection{Biological methods}

Biological methods of water purification from organic substances, including antibiotics, are based on living organisms' usage, such as bacteria of various species. One of the features of this treatment method is the ability to select certain living organisms for the optimal treatment of wastewater of given chemical composition.

Traditional biological methods of wastewater treatment have some advantages: they are more environmentally friendly, do not require complex hardware applications, have low operating costs. However, these methods also have some disadvantages, such as unsuitability for the treatment of effluents with very high chemical oxygen demand (COD). In addition, most antibiotics are toxic to the bacterial component of activated sludge and can lead to its death (Oller et al., 2011).

Therefore, taking into account the high concentrations of pollutants in the wastewater of pharmaceutical companies, including antibiotics, the use of biological treatment methods is possible only at the stage of purification after the mandatory stage of inactivation of such pollutants (Oller et al., 2011).

\subsection{Oxidation methods}

Among the methods used to purify wastewater from organic pollutants, including antibiotics, should be preferred the methods of the group of Advanced Oxidation Process (AOPs): ozonation in combination with other oxidants or irradiation, usage of the Fenton/photo-Fenton reagent, photolysis, semi-conductor photocatalysis, electrochemical processes. It is believed that AOPs contribute to the degradation or mineralization of organic pollutants, particularly antibiotics (Kyrii et al., 2019).

Such methods usually have high efficiency, the absence of secondary pollution, and a short duration of processing. Compared to traditional wastewater treatment methods, it has such advantages as strong oxidative capacity, non-selective simple 
reaction conditions, and no high temperature and pressure requirements. In addition, this method can be used in combination with other treatment technologies (Kyrii et al., 2019).

Ozonation. Ozonation includes the direct oxidation processes of organic compounds or disinfection with water-soluble ozone and oxidative processes occurring with the participation of hydroxyl radicals formed by chemical transformations of salts. The formation of hydroxyl radicals due to the transformation of ozone in the aqueous medium increases in the presence of hydrogen peroxide, catalysts, activated carbon, in combination with ozonation with ultraviolet radiation and ultrasonic treatment.

Antibiotics degradation by ozonation occurs through two mechanisms (Ikehata \& El-Din, 2004; Rekhate \& Srivastava, 2020). The first is the direct oxidation of antibiotics at lower $\mathrm{pH}$ with a highly selective process and low reaction rate, at which electrophilic attacks occur on antibiotics and convert them into fatty acids. The second is the indirect mechanism of forming hydroxyl radicals $(\bullet \mathrm{OH})$.

The advantages of the ozonation process are on-site ozone generation and no waste production. But disadvantages include high operation and energy costs, possible formation of harmful by-products and limited pollutant mineralization (Taoufik et al., 2020; Kutuzova et al., 2021).

The Fenton process. This process is based on the use of Fenton's reagent, which consists of hydrogen peroxide (oxidant) and a mixture of salt $\mathrm{Fe}^{2+}$ (catalyst). When exposed to light, the Fenton process is accelerated, which increases the degree of mineralization of organic matter and reduces operating costs.

The advantages of the Fenton process are fast, effective, and safe process, easy operation, possible mineralization of pollutants (Taoufik et al., 2020; Wang and Zhuan, 2020), However, as disadvantages are that reaction is limited to acidic conditions $\mathrm{pH}$ 2.8-3.5, large volumes of ferrous sludge produced, complicated recovery of $\mathrm{Fe}^{2+} / \mathrm{Fe}^{3+}$ ions (Taoufik et al., 2020; Kutuzova et al., 2021).

\section{Photocatalytic oxidation.}

Photocatalytic processes occur in the presence of catalysts made of semiconductor materials, in which electrons are in the free (and can move along the crystal lattice) and bound (involved in chemical bonds with ions of crystal lattices) states. Various semiconducting materials as photocatalysts, for example, metal oxides $\left(\mathrm{TiO}_{2}, \mathrm{SnO}_{2}, \mathrm{ZnO}\right.$, $\left.\mathrm{Fe}_{2} \mathrm{O}_{3}, \mathrm{Ag}_{3} \mathrm{O}_{4}\right)$, metal sulfides ( $\left.\mathrm{ZnS}, \mathrm{CdS}\right)$ are used (Lee at al., 2017; Wang et al., 2020). The efficiency of photocatalytic water treatment depends on the configuration and operating parameters of the photoreactor. Two configurations are commonly used: a suspended catalyst reactor and an immobilized catalyst reactor.

The most widely used as catalyst is $\mathrm{TiO}_{2}$ due to its specific properties. An over the past few decades, scientists have put some effort into increasing the surface area of $\mathrm{TiO}_{2}$ by dispersing $\mathrm{TiO}_{2}$ nanoparticles on a large surface area of materials (Dontsova et al., 2020).

Photocatalytic decomposition of antibiotics is very promising due to such advantages as simple in operation, highly efficient and environmentally friendly process, performed under ambient temperature and pressure and utilizes atmospheric oxygen as the oxidant, complete mineralization of organic pollutants is possible, no waste generation, efficient recovery and reuse of photocatalysts is 
possible (Kutuzova et al., 2021; Kutuzova and Dontsova, 2019; Gopinath et al., 2020). However, as in other methods, photocatalytic removal of antibiotics has several drawbacks, namely: fast recombination of photogenerated charge carriers decreases process efficiency, limited visible light response, not applicable to water with high concentrations of organic pollutants, losses of photocatalyst under longterm operation, the toxicity of by-products should be considered (Phoon et al., 2020; Wang et al., 2020). Moreover, there are theories that metals from the photocatalyst in micro quantities can remain in purified water (Kutuzova et al., 2021).

\subsection{Physico-chemical methods}

Adsorption is one of the most effective methods of advanced water purification from solutes and antibiotics. The advantages include a high purification degree and the ability to adsorb components of multicomponent mixtures. Various artificial and natural porous materials (activated carbon, ash, zeolites, peat, etc.) are used as sorbents. The efficiency of adsorption purification reaches $80-95 \%$. However, a significant disadvantage of activated carbon is its low adsorption affinity with low molecular weight polar organic substances.

Another significant disadvantage of adsorption water treatment from antibiotics is the formation of secondary waste, as they are transferred from the liquid phase of wastewater to the solid phase of adsorbents without any decomposition (Varma et al., 2020).

That is, antibiotics do not undergo any changes in the chemical structure, and therefore still retain their harmful potential and require further disposal (Bartolomeu et al., 2018).

\subsection{Membrane methods}

The membrane methods are a physical process of chemicals separation using membranes (Phoon et al., 2020; Kutuzova et al., 2021). Depending on the pore size of the membranes used, they can be microfiltration, ultrafiltration, and nanofiltration. Separately allocated reverse osmosis membranes. However, only nanofiltration and reverse osmosis can be efficiently applied to antibiotic removal from water ( $\mathrm{Lu}$ at al., 2020).

Membrane methods have such advantages as high removal efficiency and a fast and straightforward process with no chemicals involved. Disadvantages include high costs of operation and maintenance, membrane fouling, and nondestructive process (antibiotics collected on the membrane surface of the membrane without any decomposition) (Chaturvedi et al., 2021; Serhiienko et al., 2020).

\section{Conclusions}

The current review focuses on the influence of antibiotics contamination of natural water on the environment, aquatic biosystems, and public health and possible methods of its removal.

Low concentrations of antibiotics cause an occurrence of pathogenic microorganisms which are resistant to antibiotics that very negatively influence public health. Thereby, rigorous treatment of antibiotic-containing wastewater is essential for decreasing of harmful action of anthropogenic activity on the environment and public health.

Unfortunately, existing treatment systems do not meet the current challenge of antibiotic removal, which necessitates the search for new approaches and treatment methods. 
The methods of removal and decomposition of antibiotics such as biological, oxidative (ozonation, Fenton process, photocatalytic oxidation), physicochemical, and membrane are considered in the paper. The peculiarities of these processes, their advantages and disadvantages are established.

Among all the proposed methods, photocatalysis has shown massive potential as an efficient, cost-effective, and energyefficient advanced oxidation process that can decompose and mineralize antibiotics to safe and straightforward substances.

\section{Acknowledgments}

The authors thank students of National Technical University of Ukraine «Igor Sikorsky Kyiv Polytechnic Institute» for actively participating in the discussion on the study topic.

\section{References}

1. Patel, N.; Khan, M. D. Z. A.; Shahane, S.; Rai, D.; Chauhan, D.; Kant, C.; Chaudhary, V. K. Emerging Pollutants in Aquatic Environment: Source, Effect, and Challenges in Biomonitoring and Bioremediation- A Review. Pollution 2020, 6 (1), 99113. https://doi.org/10.22059/poll.2019.285116.646

2. Kumararaja, P.; Suvana, S.; Saraswathy, R.; Lalitha, N.; Muralidhar, M. Mitigation of Eutrophication through Phosphate Removal by Aluminium Pillared Bentonite from Aquaculture Discharge Water. Ocean \& Coastal Management 2019, 182, 104951.

https://doi.org/10.1016/j.ocecoaman.2019.104951

3. Tomchenko, O.; Panchenko, R.; Mazurkevich, L. Change Monitoring of the Dnipro River within Kyiv Using Satellite Information. Water and Water Purification Technologies. Scientific and Technical News 2020, 27 (2), 97-107.

4. Grenni, P.; Ancona, V.; Barra Caracciolo, A. Ecological Effects of Antibiotics on Natural Ecosystems: A Review. Microchemical Journal 2018, 136, 25-39.

http://dx.doi.org/10.1016/j.microc.2017.02.006
5. Willyard, C. The Drug-Resistant Bacteria That Pose the Greatest Health Threats. Nature 2017, 543 (7643), 15-15.

https://doi.org/10.1038/nature.2017.21550

6. Roy, N.; Alex, S. A.; Chandrasekaran, N.; Mukherjee, A.; Kannabiran, K. A Comprehensive Update on Antibiotics as an Emerging Water Pollutant and Their Removal Using Nano-Structured Photocatalysts. Journal of Environmental Chemical Engineering 2021, 9 (2), 104796.

https://doi.org/10.1016/j.jece.2020.104796

7. Jiang, L.; Hu, X.; Xu, T.; Zhang, H.; Sheng, D.; Yin, D. Prevalence of Antibiotic Resistance Genes and Their Relationship with Antibiotics in the Huangpu River and the Drinking Water Sources, Shanghai, China. Science of The Total Environment 2013, 458-460, 267-272.

https://doi.org/10.1016/j.scitotenv.2013.04.038

8. Tang, J.; Wang, S.; Fan, J.; Long, S.; Wang, L.; Tang, C.; Tam, N. F.; Yang, Y. Predicting Distribution Coefficients for Antibiotics in a River Water-Sediment Using Quantitative Models Based on Their Spatiotemporal Variations. Science of The Total Environment 2019, 655, 1301-1310. https://doi.org/10.1016/j.scitotenv.2018.11.163

9. Wang, X.-H.; Lin, A. Y.-C. Phototransformation of Cephalosporin Antibiotics in an Aqueous Environment Results in Higher Toxicity. Environmental Science \& Technology 2012, 46 (22), 12417-12426. https://doi.org/10.1021/es301929e

10. Cheng, D.; Liu, X.; Li, J.; Feng, Y.; Wang, J.; Li, Z. Effects of the Natural Colloidal Particles from One Freshwater Lake on the Photochemistry Reaction Kinetics of Ofloxacin and Enrofloxacin. Environmental Pollution 2018, 241, 692-700. https://doi.org/10.1016/j.envpol.2018.06.017

11. Ge, L.; Chen, J.; Wei, X.; Zhang, S.; Qiao, X.; Cai, X.; Xie, Q. Aquatic Photochemistry of Fluoroquinolone Antibiotics: Kinetics, Pathways, and Multivariate Effects of Main Water Constituents. Environmental Science \& Technology 2010, 44 (7), 2400-2405. https://doi.org/10.1021/es902852v

12. Xu, J.; Xu, Y.; Wang, H.; Guo, C.; Qiu, H.; He, Y.; Zhang, Y.; Li, X.; Meng, W. Occurrence of Antibiotics and Antibiotic Resistance Genes in a Sewage Treatment Plant and Its Effluent-Receiving River. Chemosphere 2015, 119, 1379-1385. https://doi.org/10.1016/j.chemosphere.2014.02.040

13. Jiang, M.; Wang, L.; Ji, R. Biotic and Abiotic Degradation of Four Cephalosporin Antibiotics 
in a Lake Surface Water and Sediment. Chemosphere 2010, $80 \quad$ (11), 1399-1405. https://doi.org/10.1016/j.chemosphere.2010.05.048

14. Binh, V. N.; Dang, N.; Anh, N. T.; Ky, L. X.; Thai, P. K. Antibiotics in the Aquatic Environment of Vietnam: Sources, Concentrations, Risk and Control Strategy. Chemosphere 2018, 197, 438-450.

https://doi.org/10.1016/j.chemosphere.2018.01.061

15. Mansouri F.; Chouchene K.; Ksibi M. Removal of Pharmaceuticals from Water by Adsorption and Advanced Oxidation Processes: State of the Art and Trends. Applied science 2021, 11(14), 6659. https://doi.org/10.3390/app11146659

16. Balcioglu, I.; Ötker, M. Treatment of pharmaceutical wastewater containing antibiotics by $\mathrm{O}_{3}$ and $\mathrm{O}_{3} / \mathrm{H}_{2} \mathrm{O}_{2}$ processes. Chemosphere 2003, 50, 85-95.

17. Oller, I.; Malato, S.; Sánchez-Pérez, J. Combination of Advanced Oxidation Processes and biological treatments for wastewater decontamination A review. Science of the total environment 2011, 409, 4141-4166.

18. Kyrii S.; Krimets G.; Kosogina I.; Astrelin I.; Fedorenko O. Applying AOPs for antibiotics extraction from wastewater. Norwegian Journal of development of the International Science 2019, 26, 2631.

19. Ikehata, K.; El-Din, M.G. Degradation of recalcitrant surfactants in wastewater by ozonation and advanced oxidation processes: a review. Ozone: Science \& Engineering 2004, 26, 327-343. https://doi.org/10.1080/01919510490482160.

20. Rekhate, C.V.; Srivastava, J.K. Recent advances in ozone-based advanced oxidation processes for treatment of wastewater- a review. Chemical Engineering Journal Advances 2020 3, 100031. https://doi.org/10.1016/j.ceja.2020.100031.

21. Taoufik, N.; Boumya, W.; Janani, F.Z.; Elhalil, A.; Mahjoubi, F.Z.; Barka, N. Removal of emerging pharmaceutical pollutants: A systematic mapping study review. J. Environ. Chem. Eng. 2020, 8, 104251. https://doi.org/10.1016/j.jece.2020.104251

22. Kutuzova, A.; Dontsova,T.; Kwapinski, W. Application of $\mathrm{TiO}_{2}$-Based Photocatalysts to Antibiotics Degradation: Cases of Sulfamethoxazole, Trimethoprim and Ciprofloxacin. Catalysts 2021, 11, 728. https://doi.org/10.3390/ catal11060728

23. Wang, J.; Zhuan, R. Degradation of antibiotics by advanced oxidation processes: An overview. Sci. Total Environ. 2020, 701, 135023. https://doi.org/10.1016/j.scitotenv.2019.135023

24. Lee, C.M.; Palaniandy, P.; Dahlan, I. Pharmaceutical residues in aquatic environment and water remediation by $\mathrm{TiO}_{2}$ heterogeneous photocatalysis: A review. Environ. Earth Sci. 2017, 76, 611. https://doi.org/10.1007/s12665-017-6924-y

25. Dontsova, T.A.; Kutuzova, A.S.; Bila, K.O.; Kyrii, S.O.; Kosogina, I.V.; Nechyporuk, D.O. Enhanced Photocatalytic Activity of $\mathrm{TiO}_{2} / \mathrm{SnO}_{2}$ Binary Nanocomposites. J. Nanomater. 2020, 2020, 1-13. https://doi.org/10.1155/2020/8349480

26. Kutuzova, A.S.; Dontsova, T.A. Characterization and properties of $\mathrm{TiO}_{2}-\mathrm{SnO}_{2}$ nanocomposites, obtained by hydrolysis method. Appl. Nanosci. $\quad 2019, \quad 9, \quad 873-880$. https://doi.org/10.1007/s13204-018-0754-4

27. Gopinath, K.P.; Madhav, N.V.; Krishnan, A.; Malolan, R.; Rangarajan, G. Present applications of titanium dioxide for the photocatalytic removal of pollutants from water: A review. J. Environ. Manag. 2020, 270 , 110906.

https://doi.org/10.1016/j.jenvman.2020.110906

28. Phoon, B.L.; Ong, C.C.; Mohamed Saheed, M.S.; Show, P.L.; Chang, J.S.; Ling, T.C.; Lam, S.S.; Juan, J.C. Conventional and emerging technologies for removal of antibiotics from wastewater. J. Hazard. Mater. $\quad 2020, \quad 400, \quad 122961$. https://doi.org/10.1016/j.jhazmat.2020.122961

29. Varma, K.S.; Tayade, R.J.; Shah, K.J.; Joshi, P.A.; Shukla, A.D.; Gandhi, V.G. Photocatalytic degradation of pharmaceutical and pesticide compounds (PPCs) using doped $\mathrm{TiO}_{2}$ nanomaterials: A review. Water-Energy Nexus 2020, 3, 46-61. https://doi.org/10.1016/j.wen.2020.03.008

30. Bartolomeu, M.; Neves, M.S.; Faustino, M.A.F.; Almeida, A. Wastewater chemical contaminants: Remediation by advanced oxidation processes. Photochem. Photobiol. Sci. 2018, 17, 15731598. https://doi.org/10.1039/C8PP00249E

31. Lu, Z.Y.; Ma, Y.L.; Zhang, J.T.; Fan, N.S.; Huang, B.C.; Jin, R.C. A critical review of antibiotic removal strategies: Performance and mechanisms. J. Water Process Eng. 2020, 38, 101681. https://doi.org/10.1016/j.jwpe.2020.101681

32. Chaturvedi, P.; Giri, B.S.; Shukla, P.; Gupta, P. Recent advancement in remediation of synthetic organic antibiotics from environmental matrices: Challenges and perspective. Bioresour. Technol. 2021, 
$319,124161$.

https://doi.org/10.1016/j.biortech.2020.124161

33. Serhiienko, A. O.; Dontsova, T. A.; Yanushevska, O. I.; Nahirniak, S. V.; HosseiniBandegharaei, A. Ceramic Membranes: New Trends and Prospects. Water Water Purif. Technol. Sci. Tech. News 2020, 27, 4-31. https://doi.org/10.20535/221893002722020208817

\title{
ПРОБЛЕМА АНТИБІОТИКІВ У ПРИРОДНИХ ВОДАХ: ОГЛЯД
}

\author{
Літинська М. I. ${ }^{1}$, Кирій С. O. ${ }^{1}$, Носовська О. Ю. ${ }^{1}$, Риженко Н. С. ${ }^{1}$ \\ ${ }^{1}$ Національний технічний університет України «Київський політехнічний інститут \\ імені Ігоря Сікорського», Україна, m.litynska-2017@kpi.ua
}

Стаття присвячена впливу забруднення природних вод антибіотиками на стан навколишнього середовища, водні біосистеми $і$ здоров'я населення та можливі шляхи вирішення иієї проблеми. Неочищені або неефективно очищені стічні води виступають джерелом різних патогенних мікроорганізмів і токсичних хімічних речовин, у тому числі органічних $i$ неорганічних сполук. Багато органічних забрудників $\epsilon$ генотоксичними, спричинюють ендокринні порушення та мають імунотоксичний вплив. У сучасному світі люди використовують багато різноманітних антибіотиків для лікування різноманітних бактеріальних інфекцій, але надмірне використання антибіотиків і їх недостатнє видалення очисними спорудами призводять до накопичення та біотрансформації ичих сполук у водному середовищі. Антибіотики є дуже шкідливими для навколишнього середовища, оскільки викликають скорочення мікробного біорізноманіття, у тому числі бактеріальних угруповань з важливими екологічними функціями. Це провокує зміну властивостей води та трунту, зокрема рH, вмісту поживних речовин, вологості трунту тощз. Низькі концентрачіі антибіотиків спричинюють появу антибіотикорезистентних патогенних мікроорганізмів, що в свою чергу вкрай негативно впливає на здоров'я населення внаслідок підвищення ризиків для здоров'я та ускладнення підбору ліків. Деякі антибіотики, в тому числі циироофлоксацин, $\epsilon$ дуже стійкими, шьо дуже шкідливо для стабільності екосистеми. У разі застосування цчипрофлоксацинових антибіотиків у поверхневих водах внаслідок прямого фотолізу відбувається утворення органічних сполук, які є токсичнішими та менш фотолабільними, ніж вихідні антибіотики. Отже, токсичність ции забрудників збільшується синергетично, $i$ це явище не можна ігнорувати. У наш час видалення антибіотиків є вкрай важливим у підготовиі питної води та очищенні стічних вод внаслідок значного впливу циих забрудників на навколишнє середовище та здоров'я. Існує багато підходів до видалення антибіотиків 3 води, зокрема адсорбиія, нанофільтрація, різноманітні окиснювальні процеси тощо. Усі иүі методи мають певні переваги та недоліки. Каталітична фотодеградація $\epsilon$ одним 3 найпопулярніших методів видалення антибіотиків, оскільки цей процес $\epsilon$ простим, високоефективним $і$ дозволяє перетворювати антибіотики на компоненти з меншими токсичністю та впливом на навколишнє середовище. Також в результаті фотокаталізу не утворюється великої кількості відходів, на відміну від коагуляџії (осад) або нанофільтрації (кониентрат).

Ключові слова: забруднення антибіотиками, видалення антибіотиків, стічні води, забруднення води, очищення води 